\title{
TOWARDS COMPETITIVE REGIONAL DEVELOPMENT THROUGH CLUSTERS: APPROACHES TO THEIR PERFORMANCE EVALUATION
}

\section{- Tvaronavičiene Manuela, Razminiene Kristina}

\begin{abstract}
It is notable that the interest in clusters and their role in sustainable regional development are increasing as scholars often review this topic. Valuable observations are made on how the clusters should be researched in order to improve their performance which would result in economic growth both on regional and national scale. Clusters' performance is complicated to evaluate as the measures of the aspects that must be calculated differ and the most appropriate solution to formalize these aspects should be found. Different multi-criteria evaluation methods are suggested by scholars for a quantitative evaluation of performance of a certain phenomenon. This study attempts to present the clusters' performance evaluation by applying the multi-criteria SAW method. Seven clusters from Lithuania and Latvia were examined to serve the purpose of this study. The multi-criteria analysis could be used as a method in further evaluation of clusters' performance for it is comprehensible, easy to apply, helpful in the data evaluation of different measures and it provides adequate results, which is very important in a quantitative analysis. The results suggest that processes are very important in clusters' performance evaluation for clusters which show good results with processes, stay in high positions, whereas clusters which are keeping behind with processes show worse results in their performance. The study still needs to be supplemented by more clusters to obtain specific information and to elaborate on more specific clusters' performance evaluation methods.
\end{abstract}

Keywords: clusters, regional development, competitiveness, multi-criteria analysis, $S A W$ method, innovations, knowledge sharing, proximity, competitiveness, R\&D

JEL Classification: F64

\section{INTRODUCTION}

It is notable that the interest in clusters and their role in sustainable regional development are increasing as scholars often review this topic. Clusters are very often associated with technology transfer (Khanagha 2017; S. Hilkevics and A. Hilkevics 2017). Valuable observations are made on how the clusters should be researched in order to improve their performance, which would result in economic growth both on regional and national scale.

The study is structured as follows. Part 1 provides the theoretical information of multi-criteria methods in quantitative evaluation. Part 2 describes the research design and the methods of data evaluation. Part 3 presents the clusters that are considered in the study and illustrates the results of the evaluation of clusters' performance. Conclusive remarks are incorporated in the final section of the study. 


\section{THEORETICAL BACKROUND}

Scientific literature suggests that innovation, knowledge sharing, social networks, collaboration, regional/ national proximity, competitiveness, research and development (R\&D) is an integral part of cluster studies (Zemlickienè et al. 2017; Razminienè et al. 2016; Rajnoha and Lesnikova, 2016; Panfiluk and Szymańska 2017; Popov et al. 2016; Kljucnikov et al. 2016; Prause and Atari 2017; Tetsman et al. 2017; Vojtovic, 2016). These phenomena are of high importance when talking about the performance of the clusters for the results depending on how they are managed and evaluated.

Different authors agree that geographic proximity is worth the attention that it gets for it enables collaboration, innovation (Letaifa and Rabeau 2013; Boschma et al. 2013; Castellani et al. 2013; D’Este et al. 2013; Maskell 2014) and knowledge sharing (Crespo et al. 2014; D’Angelo et al. 2013). In addition, social networks are analyzed to understand their relationship with innovations (Casanueva 2013; Letaifa and Rabeau 2013), production (Carswell 2013) and knowledge sharing (Lorenzen and Mudambi 2013). The scholars suggest that industry clustering has positive effect on innovation performance and knowledge (Lai et al. 2014; Tavassoli and Tavassoli 2014; Bouncken and Kraus 2013; Morrison et al. 2013; Feldman 2014). Literature study, data collection and analysis allow making a conclusion that profit making or capital accumulation can differ depending on companies' upgrade (Tokatli 2013) or path dependence (Dobusch and Schussler 2013). D'Agostino (2013) studies the relationship between a region's home and foreign investments in R\&D that affects home's regional knowledge production. Recent researches on competitiveness and clusters for regions and regional policy show that policies are mostly focused on strengthening existing agglomerations rather than establishing new ones (Ketels 2013). The concept of creating shared value which is emphasized by scholars in cluster studies has also been criticized for several reasons, such as not being original, ignoring tension between social and economic goals, being naive about the challenges of business compliance and having basis of shallow conception of the corporation's role in society. On the other hand, this concept has strengths for being successfully appealing to practitioners and scholars, elevating social goals to strategic level, articulating a clear role for governments in responsible behavior, adding rigor to ideas of "conscious capitalism" and providing an umbrella construct loosely connected concepts (Crane et al. 2014).

Despite the attempts to detect the links among these phenomena and indicate their influence on each or several factors that are analyzed by scholars, it is still complicated to evaluate the performance of the clusters. Different methods are applied in order to analyze qualitative and quantitative data, such as correlation and regression analysis (Casanueva et al. 2013; Lai et al. 2014; Tavassoli, Carbonara 2014; Crespo et al. 2014; D‘Angelo et al. 2013), gravitation model (Castellani et al. 2013), case analysis (Ben Lafeita and Rabeu 2013; Boschma et al. 2013; Bouncken and Kraus 2013; Carswell 2013; Lorenzen, Mudambi 2013; Tokatli 2013; Dobusch and Schussler 2013; Morrison et al. 2013) or literature analysis (Crane et al. 2014; D’Agostino et al. 2013; Maskell 2014; Feldman 2014; D’Este et al. 2013; Ketels 2013). The problem of providing the most effective way to evaluate the data of different phenomena, which are mentioned in clusters' studies, could be by performing a quantitative evaluation of clusters' performance (Ginevičius, A. 2007). 
Different multi-criteria evaluation methods are suggested by scholars for a quantitative evaluation of performance of a certain phenomenon (Simanaviciene and Ustinovichius 2010; Chen 2012). Ginevičiu, et al (2008) emphasize the importance of development of a set of criteria at a stage of multi-criteria evaluation of a complex phenomenon. A single level set of criteria can be provided for experts to determine the weight of each criterion if their number is small and possible to conceive. On the other hand, if there are more criteria, which makes it difficult to separate the most important ones from the less important, their number must be reduced by forming a hierarchical structure where each hierarchical level is evaluated starting with the lowest one. Hence, the criteria in each hierarchical level must have the weight determined.

\section{AIM, METHODOLOGY AND DATA}

The aim of this study is to discuss a tool, which would allow evaluating the efficiency of clusters performance in terms of knowledge transfer, understood in the most general way. Clusters' performance is complicated since it embraces wide array of facets. There are many methodologies used in decision making that share common characteristics of conflict among criteria, incomparable units, and difficulties in selection of alternatives.

Multi-criteria Decision Making is a well-known branch of decision-making. It deals with decision problems which involve a number of decision criteria. Multi-criteria Decision Making as a discipline is rather young for the models and techniques of modern multi-criteria decision making which started to develop in 1950s and 1960s when many scholars were proposing their new models and techniques of multi-criteria decision making. The interest in this field of researches and development have continuously been growing in the past decades (Zavadskas et al. 2014; Pohekar, Ramachandran 2004).

Multi-criteria decision making, as described by Vincke (1992), is the most directly characterized by a set of multiple-criteria method. The methods that have been developed since 1950s differ in the required quality and quantity of additional information, the methodology used, simplicity, the sensitivity tools used, and the mathematical properties they verify (Zavadskas et al. 2014). The main features that are shared by different methodologies are the conflict among criteria, incomparable units, difficulties in selection of alternatives. The alternatives are not predetermined in multi-criteria decision making, a set of objective functions is optimized regarding to a set of constraints. The best solution is sought by evaluating a small number of alternatives against a set of criteria which are often hard to quantify. The alternatives are sought by making comparisons between the alternatives with respect to each criterion (Pohekar, Ramachandran 2004). The multi-criteria decision process is shown in Figure 1. 


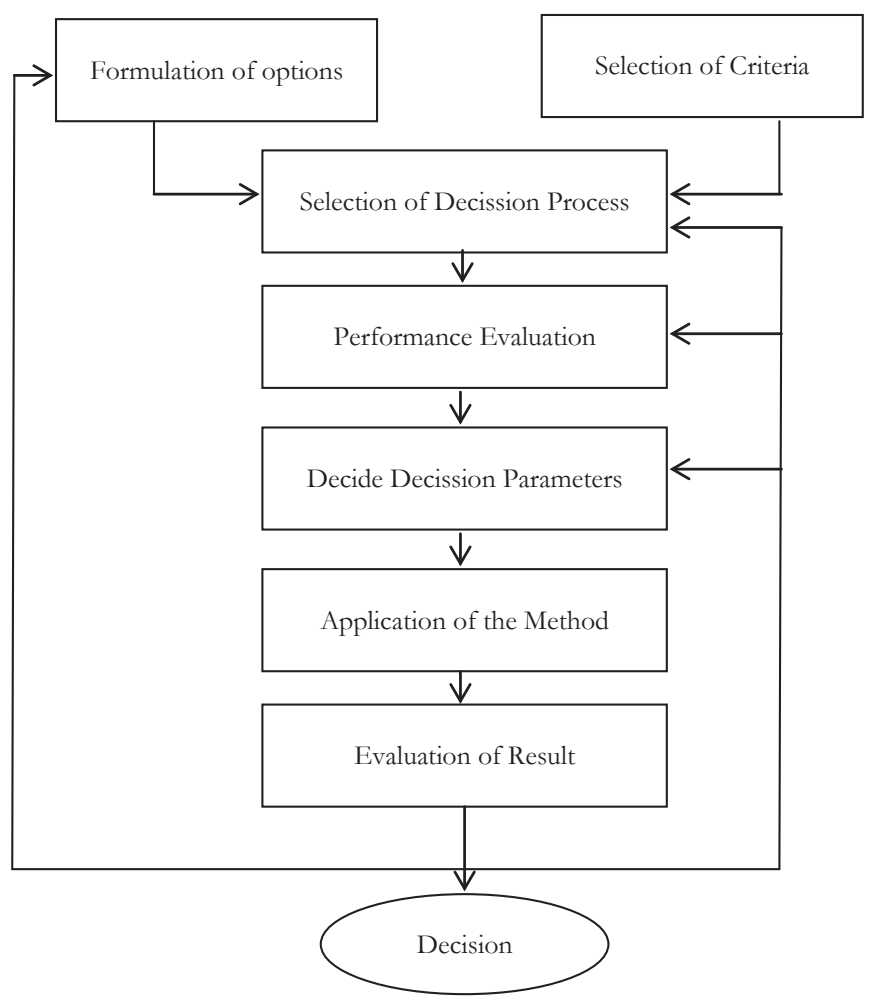

Fig. 1 - Multi-criteria decision making. Source: Pohekar and Ramachandran 2004

Multi-criteria decision making methods can be used in solving both theoretical and practical problems. They are universal for their potential to quantitatively evaluate any complicated object described by a set of criteria (Ginevičius et al. 2008). Quantitative multi-criteria evaluation methods differ in their concept, type of data normalization as well as the way of combining the data and the criteria weights into the criterion of method evaluation, variation range of the criteria values and the influence of the initial data. The important point is that it is possible to make decisions based on the results of multi-criteria analysis, compare them, and analyze the reasons for some alternatives which are leading or staying behind. The influence of a particular criterion and its weight can be detected and decision made respectively. In order to apply multi-criteria evaluation methods, the following procedures should be performed in three steps: a set of criteria describing the object considered should be developed, the criteria weights and significances should be determined and an appropriate multi-criteria evaluation method should be chosen (Ginevičius et al. 2008).

The later step includes the weights assigned by the experts. Their given weights must be reasonable and coincide with a certain degree. Since the weights of criteria are evaluated by experts, the consistency of their estimates should be checked. It is usually performed by using the concordance coefficient W and Pearson correlation coefficient $\chi^{2}$ (Kendall 1970; Podvezko 2007). 
Further processing of the results must include the multi-criteria evaluation of performance of the cluster. Multi-criteria methods are used for both theoretical and practical tasks since they are universal and enable to carry out a quantitative study for any complex phenomenon with many indices (Jakimavičius and Burinskienè 2007; Žvirblis and Zinkevičiūtè 2008; Jakimavičius and Burinskienè 2009; Shevchenko et al. 2008; Wu et al. 2009; Žvirblis and Buračas 2010; Podvezko 2011). To evaluate clusters' performance quantitatively, various aspects should be formalized, which means that the criteria should be developed and integrated into one generalized quantity. This is not a trivial task because the criteria may be multidimensional and oppositely-directed, which implies that the increasing values of some criteria may indicate that the situation is getting better whereas the increase in the values of other criteria shows that the situation is worsening. To solve these problems, multi-criteria evaluation methods, widely used in recent years, may be applied (Ginevičius et al. 2008). The multi-criteria SAW (Simple Additive Weighting) method was applied to process the results.

SAW method was developed in 1968 and applied for multi-criteria decision making in various fields, which contain multi-criteria decision making problems, group decision making, contractors ranking, performance assessment model in a sector, evaluation of certain zones, analysis and ranking (Zavadskas et al. 2010). This method is one of the simplest methods and most often used in multi-criteria decision making technique (Malczewski 1997; Janssen 1992; Eastman 1993). The method is based on the weighted average. An evaluation score is calculated for each alternative by multiplying the scaled value given to the alternative of that attribute with the weights of relative importance directly assigned by decision maker followed by summing of the products for all criteria (Şener et al. 2006).

The basic logic of SAW is to obtain a weighted sum of the performance ratings of each alternative over all attributes. The SAW method normally requires normalizing the decision matrix $(\mathrm{X})$ to allow a comparable scale for all ratings in $\mathrm{X}$ by equation 1The basic logic of SAW is to obtain a weighted sum of the performance ratings of each alternative over all attributes. The SAW method normally requires normalizing the decision matrix $(\mathrm{X})$ to have a comparable scale for all ratings in $\mathrm{X}$ by equation 1 :

$$
r_{i j}=\left\{\begin{array}{l}
\frac{x_{i j}}{\max _{i} x_{i j}}, \text { if } j \text { is a benefit attribute } \\
\frac{\min _{i} x_{i j}}{x_{i j}}, \text { if } j \text { is a cost attribute }
\end{array} \quad(i=1,2, \ldots, m, j=1,2, \ldots, n),\right.
$$

where $r_{i j}\left(0 \leq r_{i j} \leq 1\right)$ is defined as the normalized performance rating of alternative $A_{i}$ on attribute $C_{j}$. This normalization process transforms all the ratings in a linear (proportional) way, so that the relative order of magnitude of the ratings remains equal. The overall preference value of each alternative $\left(V_{i}\right)$ is obtained by equation 2 :

$$
\mathrm{v}_{i}=\sum_{j=1}^{n} w_{j} r_{i j}, \quad i=1,2, \ldots, \mathrm{m} .
$$

The greater the value ( $V i)$, the more preferred the alternative (Ai) (Chang and Yeh 2001).

In many situations, the alternatives that could be considered are originally infinite (Polatidis et 
al. 2006), so multi-criteria methods are a good solution to apply in clusters' performance evaluation as certain criteria are depicted, structuralized, their weights are determined by experts, the consistency of the experts checked and the values calculated.

The data for the researched was collected from seven Lithuanian and Latvian clusters. These clusters were indicated as the most successful in these two countries and the data provided is considered to be reliable. Data was given in different measures regarding 44 different criteria that were ascribed to indicate the most important indicators of cluster performance. It allowed making valuable observations and interpreting the results through calculations emphasizing various aspects of cluster performance.

\section{THE EVALUATION OF CERTAIN CLUSTERS' PERFORMANCE}

The purpose of quantitative evaluation of cluster performance is the effective management of the cluster after the targeted criteria are examined and all the possibilities of improving them are considered and applied. Multi-criteria analysis should perfectly serve this purpose and allow making valuable observations in cluster performance improvement after the evaluation is made. A hierarchical structure must be considered to be made for cluster performance evaluation and simple additive weighting method applied to calculate the results.

A socioeconomic system is large and complicated, therefore, the main goal is grouping the criteria describing its performance according to some particular characteristics, rather than searching for their interrelations (Ginevičius, R. 2007). The criteria that allow cluster performance evaluation are suggested by Klasterių studija (2012). 44 criteria are selected for further examination. Before providing the criteria for evaluation of the experts, a hierarchical structure must be created with different hierarchical levels for experts cannot cope with numerous criteria. The number of criteria must not exceed 12 (Ginevičius, A. 2011). For this reason a hierarchical structure must be divided into hierarchical levels depending on the connecting theme of the criteria.

This study involves seven clusters belonging to various sectors, having different characteristics described in Table1.

Tab. 1 - Successful clusters. Source: author's compilation

\begin{tabular}{|l|l|l|l|l|l|}
\hline Aluster & $\begin{array}{l}\text { Establish- } \\
\text { ment year }\end{array}$ & $\begin{array}{l}\text { Number of } \\
\text { members }\end{array}$ & Specialization & Sector \\
\hline A & $\begin{array}{l}\text { Vilnius Film } \\
\text { Cluster }\end{array}$ & 2011 & 22 & $\begin{array}{l}\text { Cinema and ad- } \\
\text { vertising }\end{array}$ & $\begin{array}{l}\text { Services, chang- } \\
\text { ing clients' } \\
\text { physical or mental } \\
\text { qualities }\end{array}$ \\
\hline B & $\begin{array}{l}\text { Wellness } \\
\text { Cluster iVita }\end{array}$ & 2011 & 11 & Health promotion & $\begin{array}{l}\text { Services, chang- } \\
\text { ing clients' } \\
\text { physical or mental } \\
\text { qualities }\end{array}$ \\
\hline
\end{tabular}




\begin{tabular}{|l|l|l|l|l|l|}
\hline C & $\begin{array}{l}\text { Laser and } \\
\text { Engineering } \\
\text { Technolo- } \\
\text { gies Cluster } \\
\text { (LITEK) }\end{array}$ & 2011 & 13 & $\begin{array}{l}\text { Lasers and laser } \\
\text { components }\end{array}$ & $\begin{array}{l}\text { Electronics } \\
\text { industry }\end{array}$ \\
\hline $\begin{array}{l}\text { Baltic } \\
\text { Automotive } \\
\text { Components } \\
\text { Cluster } \\
\text { (BACC) }\end{array}$ & 2013 & 17 & $\begin{array}{l}\text { Engineering } \\
\text { industry (manu- } \\
\text { facturing of } \\
\text { machinery and } \\
\text { devices) }\end{array}$ & $\begin{array}{l}\text { Metal machinery } \\
\text { and equipment } \\
\text { manufacturing } \\
\text { industry }\end{array}$ \\
\hline $\begin{array}{l}\text { and Healthy } \\
\text { Food Cluster } \\
\text { (LHAVHFC) }\end{array}$ & 2010 & 31 & $\begin{array}{l}\text { Food Processing } \\
\text { and Manufactur- } \\
\text { ing }\end{array}$ & $\begin{array}{l}\text { Food and bever- } \\
\text { age industry }\end{array}$ \\
\hline F & $\begin{array}{l}\text { Smart Food } \\
\text { Cluster }\end{array}$ & 2013 & 9 & $\begin{array}{l}\text { Food Processing } \\
\text { and Manufactur- } \\
\text { ing }\end{array}$ & $\begin{array}{l}\text { Food and bever- } \\
\text { age industry }\end{array}$ \\
\hline G & $\begin{array}{l}\text { Information and } \\
\text { tive Cluster } \\
\text { communication } \\
\text { technologies; crea- } \\
\text { tive industries }\end{array}$ & $\begin{array}{l}\text { Services, chang- } \\
\text { ing clients' } \\
\text { physical or mental } \\
\text { qualities }\end{array}$ \\
\hline
\end{tabular}

A hierarchical structure was made according to the common themes for experts who would be able to evaluate the importance of each criterion (Figure 2) (see Appendices). The main purpose is to provide an adequate number of criteria in one group which should not exceed 12 criteria. In this case, the maximum number is 10 for it is still possible to process this number of criteria and they were divided into groups according to the theme that they are connected to/with. The main components are resources, activities and processes in clusters' performance and the criteria that are singled out giving the measures for these components.

The questionnaire survey which was submitted in clusters served asked to evaluate the indicators in different ways. The resources were measured in units or euros as the question was to give exact numbers of resources that were adapted in the cluster. The same situation was with processes as clusters needed to provide information about expenses, change in a number of different indicators, exact numbers of indicators. The situation was different with activities as clusters were asked to evaluate the indicators given by rating them from 1 to 10 according to the clusters' performance. Communication activities and Marketing activities took the same weight in total Activities as they are of the same importance. International processes together with HRM processes also had the same weights ascribed in total Processes.

To sum up, all three groups contain features that are characterized by scholars in their works as seen from the literature analysis (also see Tvaronavičienè et al., 2015). This enables to distinguish the most important features that show cluster efficiency, which are innovative knowledge shar- 
ing, common distribution channels, qualified human resources, initiatives. All these features are most comprehensively reflected in processes and activities. Although activities do not reveal definitive figures, they show more personal opinion than numbers in processes. Hence, processes must get more prominence in counting the cluster efficiency (Razminienè et al. 2016).

The indicators of cluster performance are put into three major groups: resources, activities and processes, which were found to be important after the literature analysis. Resources include indicators which can be evaluated in numbers, both in terms of money and units (Table 2). This group represents the characteristics of a cluster, cluster's profile with the official information and statistics. The second group represents activities which cannot be measured in units, or this kind of evaluation would be inaccurate; hence, activities were asked to be measured according to their importance, ascribing points from 1 to 10 , where 1 means a low importance, 10 means a high importance. The last group are processes with the data provided in per cent or units for an objective evaluation in further calculations.

According to conclusions that were made after the literature analysis, processes were given the weight of 0.7 while activities and resources share the equal weight of 0.15 . The proportion was chosen as universal for all the clusters in different industries, so there is an assumption that it may be altered in further researches depending on the industry and the clusters' profile. In this study, it is considered to be adequate as it enables discussion for further application and development of the calculation of the final results.

Tab. 2 - Results of multi-criteria evaluation of clusters' performance. Source: authors' compilation

\begin{tabular}{|l|l|l|l|l|}
\hline & Resources & Activities & Processes & Total \\
\hline A & 0.07 & 0.18 & 0.16 & 0.15 \\
\hline B & 0.11 & 0.10 & 0.25 & 0.21 \\
\hline C & 0.04 & 0.13 & 0.05 & 0.06 \\
\hline D & 0.25 & 0.11 & 0.14 & 0.15 \\
\hline E & 0.16 & 0.11 & 0.10 & 0.11 \\
\hline F & 0.14 & 0.17 & 0.12 & 0.13 \\
\hline G & 0.24 & 0.19 & 0.17 & 0.18 \\
\hline
\end{tabular}

Table 2 provides the results of the multi-criteria analysis where the total weights determined the results. There were several phases of the study with different criteria which were provided for experts to evaluate and give the weights. A hierarchical structure was composed to limit the number of criteria which needed to be valued for experts who are able to cover only a limited number of criteria (in this case, the number was limited to 8-10 criteria). The later stage covered the literature analysis which helped to determine the weights of the main components in clusters' performance evaluation. The literature analysis showed that the processes are the most important in clusters' performance and should be given a greater weight than recourses and activities. Hence, the resources and activities should share the equal values. 
The research revealed several important findings of clusters' performance evaluation. A number of criteria should be involved in the calculations with different measures suggested by scholars. These criteria must be verified in several stages of calculations, giving them different prominence to get a universal formula for evaluation of clusters' performance belonging to various sectors.

This study revealed that a particular group of criteria, which implies that the results could be affected by putting emphasis on some specific measures, mostly determines clusters' performance. The result was observed through changing the values for groups of criteria. Processes were observed as the most influential group for changing the values of all three groups does not affect the distribution of clusters significantly if a cluster shows good results in processes. Moreover, clusters with lower results in processes show even worse results in clusters' performance.

The results in Table 2 can be used for further case study in a deeper analysis of clusters and their performance. Benchmarking could be employed to compare the criteria and to make observations of what can be done in order to achieve better results and to create value. The study is still open and more research must be done paying attention to the different nature of clusters as they specialize in different industries and their concentration on every individual criterion may differ. It may be helpful for companies in clusters to identify their strengths and weaknesses and indicate possibilities of performance improvement.

\section{CONCLUSIONS}

The interest in clusters was growing in the last century. The access to foreign markets, sources of foreign investments, and global knowledge networks are essential ingredients to the growth and development prospects of low and middle-income countries. These are the main issues that companies in clusters aim at. Clusters represent a complex form of organization, in which social ties (the community), productive networks of local firms, and the web of local institutions and collective agents form a co-operative and competitive density. Clusters are a characteristic phenomenon in local or regional markets, but their function is to build a competitive advantage for cluster members on a larger scale - not only national but international as well.

Companies today experience many challenges as well as meet the opportunities because of continuing technological revolution. The aim of companies is to enhance competencies and create competitive advantages in global competition and this can be achieved through pulling from a common and accessible pool of resources, information and demand for innovation, which means that companies can profit from belonging to a cluster. Cluster studies can be a useful pool of information for policy makers as well as company managers in helping companies to gain a competitive advantage and become successful in markets.

The research revealed that companies in clusters should contain some similar features expressed through three groups of indicators to achieve competitive advantage against other companies not belonging to clusters. As indicators are evaluated in different measures, their importance against others may be considered as unequal. This allows further interpretation of the results by giving those groups of indicators adequate significance in accordance to the credibility of measures provided. 
The results suggest that knowledge sharing, innovativeness, common distribution channels, qualified human resources and initiatives should be referred to as the most important indicators of clusters' performance. These main indicators are included in processes and activities. Here, processes are evaluated in exact numbers whereas activities reflect the degree of fulfilment expressed through rating. Hence, the evaluation system is suggested, which implies that processes are the most important in clusters' performance evaluation, while processes and activities share the same value.

As the literature analysis implies, the most important indicators are ascribed to processes, for which the weights given regarding these three groups were changed, and the clusters which show good results with processes stay in high positions, whereas the clusters that are keeping behind with processes show even worse results in clusters' performance. This system of indicators could be used in further research to detect if these three groups of indicators should be rated the same for clusters belonging to different sectors.

\section{References}

1. Ben Letaifa, S., \& Rabeau, Y. (2013). Too close to collaborate? How geographic proximity could impede entrepreneurship and innovation. Journal of business research, 66(10), 2071-2078. https://doi.org/10.1016/j.jbusres.2013.02.033.

2. Boschma, R.., Minondo, A., \& Navarro, M. (2013). The Emergence of New Industries at the Regional Level in Spain: A Proximity Approach Based on Product Relatedness. Economic geography, 89(1), 29-51. https://doi.org/10.1111/j.1944-8287.2012.01170.x.

3. Bouncken, R. B., \& Kraus, S. (2013). Innovation in knowledge-intensive industries: The double-edged sword of competition. Journal of business research, 66(10), 2060-2070. https://doi. org/10.1016/j.jbusres.2013.02.032.

4. Carswell, G. (2013). Dalits and local labour markets in rural India: experiences from the Tiruppur textile region in Tamil Nadu. Transactions of the institute of British geographers, 38(2), 325-338. https://doi.org/10.1111/j.1475-5661.2012.00530.x.

5. Casanueva, C., Castro, I., \& Galan, JL. (2013). Informational networks and innovation in mature industrial clusters. Journal of business research, 66(5), 603-613. https://doi.org/10.1016/ j.jbusres.2012.02.043.

6. Castellani, D., Jimenez, A., \& Zanfei, A. (2013). How remote are R\&D labs? Distance factors and international innovative activities. Journal of international business studies, 44(7), 649-675. https://doi.org/10.1057/jibs.2013.30.

7. Chang, YH., \& Yeh, CH. (2001). Evaluating airline competitiveness using multiattribute decision making. Omega, 29(5), 405-415.

8. Chen, TY. (2012). Comparative analysis of SAW and TOPSIS based on interval-valued fuzzy sets: Discussions on score functions and weight constraints. Expert systems with applications, 39 (1), 1848-1861.

9. Crane, A., Palazzo, G., Spence, LJ., \& Matten, D. (2014). Contesting the Value of "Creating Shared Value. California management review 56(2), 130-149. https://doi.org/10.1525/ cmr.2014.56.2.130. 
10. Crespo, J., Suire, R., \& Vicente, J. (2014). Lock-in or lock-out? How structural properties of knowledge networks affect regional resilience. Journal of economic geography, 14(1), 199-219. https://doi.org/10.1093/jeg/lbt006.

11. D’Agostino, LM., Laursen, K., \& Santangelo, GD. (2013). The impact of R\&D offshoring on the home knowledge production of OECD investing regions. Journal of economic geography, 13(1), 145-175. https://doi.org/10.1093/jeg/lbs012.

12. D’Angelo, A., Majocchi, A., Zucchella, A., \& Buck, T. (2013). Geographical pathways for SME internationalization: insights from an Italian sample. International marketing review, 30(2), 80-105. https://doi.org/10.1108/02651331311314538.

13. D’Este, P., Guy, F., I\& ammarino, S. (2017) Shaping the formation of university-industry research collaborations: what type of proximity does really matter? Journal of economic geography, 13(4), 537-558. https://doi.org/10.1093/jeg/lbs010.

14. Dobusch, L., \& Schussler, E. (2013). Theorizing path dependence: a review of positive feedback mechanisms in technology markets, regional clusters, and organizations. Industrial and corporate change, 22(3), 617-647. https://doi.org/10.1093/icc/dts029.

15. Eastman, JR. (1993) IDRISI: a grid based geographic analysis system, version 4.1. Graduate School of Geography, Clark University, Worcester.

16. Feldman, MP. (2014). The character of innovative places: entrepreneurial strategy, economic development, and prosperity. Small business economics, 43(1), 9-20. https://doi. org/10.1007/s11187-014-9574-4.

17. Ginevičius, A. (2007). Quantitative evaluation of enterprise marketing effectiveness. Technological and Economic Development of Economy, 13(1), 19-23.

18. Ginevičius, R. (2007). Hierarchical structuring of processes and phenomena. Business: Theory and Practice, 8(1), 14-18, 2007 (in Lithuanian).

19. Ginevičius, A. (2011). Increasing Economic Effectiveness of Marketing, Doctoral Dissertation. Vilnius: Technika.

20. Ginevičius, R., Podvezko, V., \& Raslanas, S. (2008), Evaluating the alternative solutions of wall insulation by multicriteria methods. Journal of Civil Engineering and Management, 14(4), 217-226.

21. Hilkevics, S., \& Hilkevics, A. (2017). The comparative analysis of technology transfer models. Entrepreneurship and Sustainability Issues, 4(4), 540-558. https://doi.org/10.9770/ jesi.2017.4.4(11).

22. Jakimavičius, M., \& Burinskienè, M. (2007). Automobile transport system analysis and ranking in Lithuanian administrative regions. Transport, 22(3), 214-220. https://doi. org $/ 10.1080 / 16484142.2007 .9638127$.

23. Jakimavičius, M., \& Burinskienè, M. (2009). A GIS and multi-criteria-based analysis and ranking of transportation zones of Vilnius city. Technological and Economic Development of Economy, 15(1), 39-48. https://doi.org/10.3846/1392-8619.2009.15.39-48.

24. Janssen, R. (1992). Multiobjective decision support for environmental management. Kluwer, Dordrecht. 
25. Jucevičius, R., Kiškienė, A., Leichteris, E., \& Stumbrytè, G. (2012). Klasteriu studija, Žinių ekonomikos forumas.

26. Kendall, M. (1970) Rank Correlation Methods. 4th ed. London: Griffin.

27. Ketels, C. (2013). Recent research on competitiveness and clusters: what are the implications for regional policy? Cambridge journal of region's economy and society, 6(2), 269-284. https://doi.org/10.1093/cjres/rst008.

28. Khanagha, A., Dehkordi, AM, Zali, MR., \& Hejazi, SR. (2017). Performance implications of entrepreneurial orientation at public research and technology institutions, Entrepreneurship and Sustainability Issues, 4(4), 601-610. https://doi.org/10.9770/jesi.2017.4.4(15).

29. Kljucnikov, A., Belas, J., Kozubikova, L., \& Pasekova, P. (2016). The Entrepreneurial Perception of SME Business Environment Quality in the Czech Republic. Journal of Competitiveness, 8(1), 66-78. https://doi.org/10.7441/joc.2016.01.05.

30. Lai, YL., Hsu, MS., Lin, FJ., Chen, YM., \& Lin, YH. (2014), The effects of industry cluster knowledge management on innovation performance. Journal of business research 67(5), 34-739. https://doi.org/10.1016/j.jbusres.2013.11.036.

31. Lorenzen, M., \& Mudambi, R. (2013). Clusters, Connectivity and Catch-up: Bollywood and Bangalore in the Global Economy, Journal of economic geography, 13(3), 501-534. https://doi. org/10.1093/jeg/lbs017.

32. Malczewski, J. (1997). Propagation of errors in multicriteria location analysis: a case study, Fandel G, Gal T (eds) Multiple criteria decision making. Springer, Berlin Heidelberg New York. 154-155.

33. Maskell, P. (2014). Accessing remote knowledge-the roles of trade fairs, pipelines, crowdsourcing and listening posts. Journal of economic geography, 14(5), 883-902. https://doi. org $/ 10.1093 /$ jeg $/ \mathrm{lbu} 002$.

34. Morrison, A., Rabellotti, R., \& Zirulia L. (2013). When Do Global Pipelines Enhance the Diffusion of Knowledge in Clusters? Economic geography, 89(1), 77-96, 2013. https://doi. $\operatorname{org} / 10.1111 /$ j.1944-8287.2012.01167.x.

35. Panfiluk, E., \& Szymańska, E. (2017). The measurement of the innovativeness of health tourism services using an adequacy matrix title of the article. Entrepreneurship and Sustainability Issues, 4(4), 400-420. https://doi.org/10.9770/jesi.2017.4.4(1).

36. Podvezko, V. (2007). Determining the level of agreement of expert estimates. International Journal of Management and Decision Making, 8(5/6), 586-600.

37. Podvezko, V. (2011). The Comparative Analysis of MCDA Methods SAW and COPRAS. Inzinerine Ekonomika-Engineering Economics, 22(2): 134-146.

38. Pohekar, SD., \& Ramachandran, M. (2004). Application of multi-criteria decision making to sustainable energy planning--A review. Renewable and sustainable energy reviews, 8(4), 365 381. https://doi.org/10.1016/j.rser.2003.12.007.

39. Polatidis, H., Haralambopoulos, DA., Munda, G., \& Vreeker R. (2006). Selecting an Appropriate Multi-Criteria Decision Analysis Technique for Renewable Energy Planning. Energy Sources, Part B: Economics, Planning, and Policy, 1(2), 181-193. https://doi.org/10.1080/00 9083190881607. 
40. Popov, E.V., Simonova, V.L., \& Kazakova, D.M. (2016). Investigation of Institutional Clustering: Empirical Evidence. Montenegrin Journal of Economics, 12 (1), 65-74.

41. Prause, G., \& Atari S. (2017). On sustainable production networks for Industry 4.0. Entrepreneurship and Sustainability Issues, 4(4), 421-431. https://doi.org/10.9770/jesi.2017.4.4(2).

42. Rajnoha, R., \& Lesníková, P. (2016). Strategic Performance Management System and Corporate Sustainability Concept - Specific Parametres in Slovak Enterprises. Journal of Competitiveness, 8 (3), 107-124. http://doi.org./10.7441/joc.2016.03.07.

43. Razminienė, K., Tvaronavičienè, M., \& Zemlickienė V. (2016). Evaluation of cluster efficiency measurement tool. Terra economicus, 14(3), 101-111.

44. Şener, B., Süzen, ML., \& Doyuran, V. (2006). Landfill site selection by using geographic information systems. Environmental Geology, 49(3). 376-388. https://doi.org/10.1007/s00254005-0075-2.

45. Shevchenko, G., Ustinovičius, L., \& Andruškevičius, A. (2008). Multi-attribute analysis of investments risk alternatives in construction. Technological and Economic Development of Economy. 14(3), 428-443. https://doi.org/10.3846/1392-8619.2008.14.428-443.

46. Simanaviciene, R., \& Ustinovichius, L. (2010), Sensitivity Analysis for Multiple Criteria Decision Making Methods: TOPSIS and SAW. Procedia Social and Behavioral Sciences 2 (1), 7743-7744. https:/doi.org/10.1016/j.sbspro.2010.05.207

47. Tavassoli, S., \& Carbonara, N. (2014). The role of knowledge variety and intensity for regional innovation. Small business economics, 43(2), 493-509. https://doi.org/10.1007/s11187014-9547-7.

48. Tetsman, I., Baziené, K., \& Viselga, G. (2017). Technologies for sustainable circular business: using crushing device for used tires. Entrepreneurship and Sustainability Issues, 4(4), 432-440. https://doi.org/10.9770/jesi.2017.4.4(3).

49. Tokatli, N. (2013), Toward a better understanding of the apparel industry: a critique of the upgrading literature. Journal of economic geography, 13(6), 993-1011. https://doi.org/10.1093/ jeg/lbs043.

50. Tvaronavičienè, M., Razminienè, K., \& Piccinetti, L. (2015). Aproaches towards cluster analys. Economics \& sociology: journal of scientific papers, 8(1), 19-27.

51. Wu, HY., Tzeng, GH., \& Chen, YH. (2009). A fuzzy MCDM approach for evaluating banking performance based on Balanced Scorecard. Expert Systems with Applications, 36(6). 10135-10147. https://doi.org/10.1016/j.eswa.2009.01.005.

52. Zavadskas, EK., \& Turskis, Z. (2011). Multiple criteria decision making. Technological and economic development of economy, 17(2), 397-427. https://doi.org/10.3846/20294913.2011.593291.

53. Zavadskas, EK, Turskis, Z., \& Kildienè, S. (2014). State of art surveys of overviews on MCDM/MADM methods. Technological and economic development of economy, 20(1), 165-179. https://doi.org/10.3846/20294913.2014.892037.

54. Zavadskas, EK., Vilutienè, T., Turskis, Z., \& Tamošaitienè, J. (2010), Contractor selection for construction works by applying sawg and topsis grey techniques. Journal of Business Economics and Management, 11(1), 34-55. 
55. Vincke, P. (1992). Multicriteria Decision Aid. Wiley: New York, 1992.

56. Vojtovic, S. (2016). The Impact of the Structural Funds on Competitiveness of Small and Medium-Sized Enterprises. Journal of Competitiveness, 8 (4), 30-45. https://doi.org/10.7441/ joc.2016.04.02.

57. Zemlickiene, V., Mačiulis, A., \& Tvaronavičienè M. (2017). Factors impacting the commercial potential of technologies: expert approach. Technological and Economic Development of Economy 23(2), 410-42. https://doi.org/http://dx.doi.org/10.3846/20294913.2016.1271061.

58. Žvirblis, A., \& Buračas, A. (2010). The consolidated measurement of the financial markets development: the case of transitional economies. Technological and Economic Development of Economy 16(2): 266-27. https://doi.org/10.3846/tede.2010.17.

59. Žvirblis, A., \& Zinkevičiūtè, V. (2008). The integrated evaluation of the macro environment of companies providing transport services. Transport, (23)3, 266-272. https:// doi.org/10.3846/1648-4142.2008.23.266-272.

\section{Contact information}

Prof. Tvaronavičiene Manuela

Vilnius Gediminas Technical University, Faculty of Business Management

Sauletekio al. 11, 10223, Vilnius, Lithuania

Email:manuela.tvaronaviciene@vgtu.lt

Razminiene Kristina

Vilnius Gediminas Technical University, Faculty of Business Management

Sauletekio al. 11, 10223, Vilnius, Lithuania

Email:kristina.razminiene@vgtu.lt 


\section{Appendix}

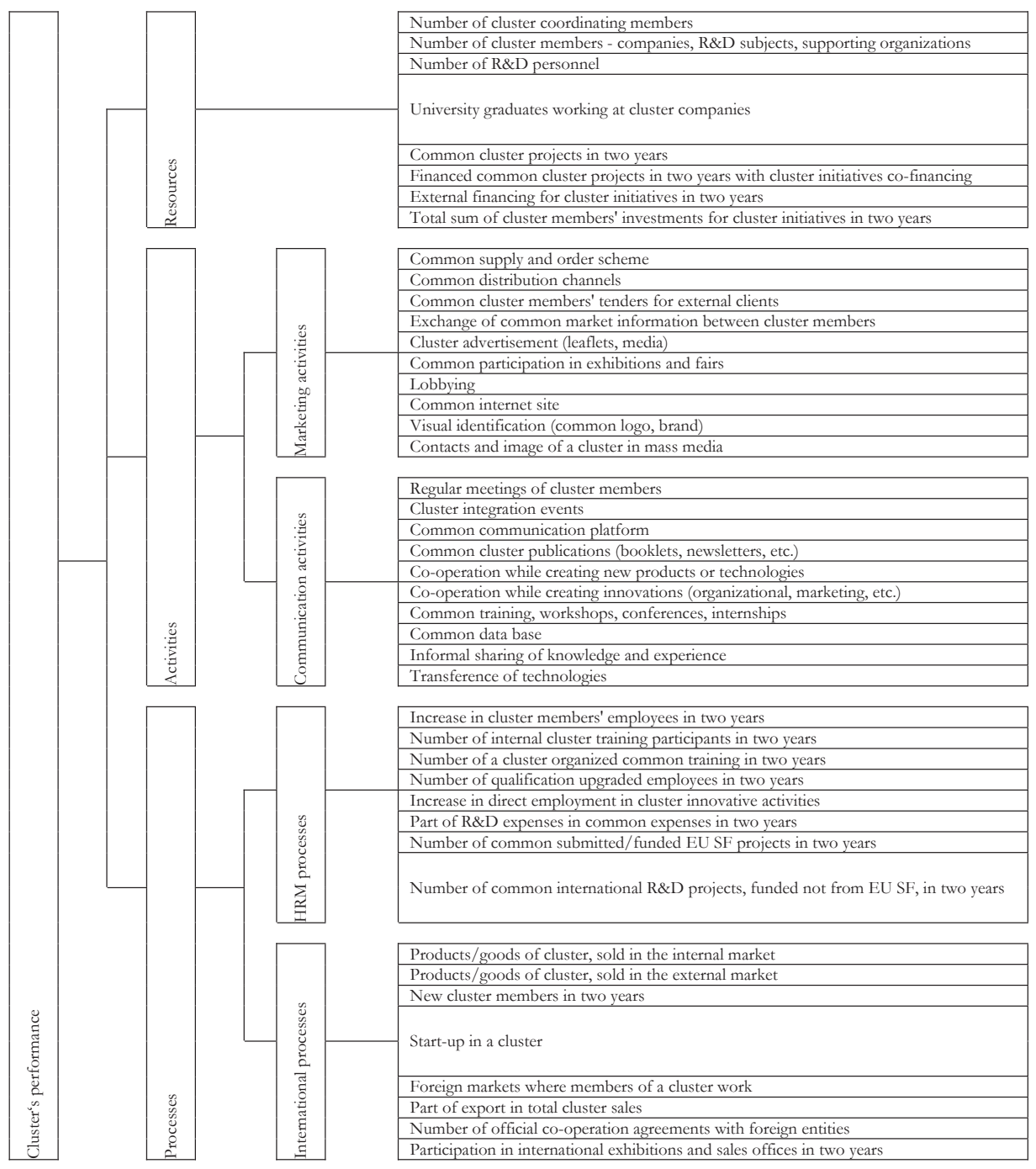

Fig. 1 - Hierarchical structure of clusters' performance evaluation. Source: Klasteriu studija (2012) 